\title{
Aspek Medikolegal dan Tata Laksana Persetujuan Tindakan Kedokteran
}

\section{Medicolegal Aspect and Procedure of Informed Consent}

\author{
Dedi Afandi ${ }^{1 *}$ \\ ${ }^{1}$ Kelompok Jabatan Fungsional (KJF) Kedokteran Forensik dan Legal, Fakultas Kedokteran Universitas Riau
}

\begin{abstract}
ABSTRAK
Persetujuan Tindakan Kedokteran (PTK) atau informed consent merupakan salah satu kewajiban yang harus dilakukan oleh dokter sebelum melakukan tindakan medis. Pelaksanaan PTK yang kurang adekuat atau tidak sesuai dengan prosedur dapat menimbulkan komplain dan atau klaim baik dari pasien maupun keluarga serta dapat menimbulkan masalah hukum bagi dokter. Tinjauan pustaka ini bertujuan untuk membahas aspek medikolegal dan tata laksana dalam proses melakukan PTK bagi dokter baik di rumah sakit maupun di fasilitas pelayanan kesehatan lainnya. Sejarah, filosofi, definisi, dasar hukum, tujuan, aspek medikolegal dan tata laksana PTK dibahas dan didiskusikan untuk meningkatkan pemahaman proses PTK yang benar. Dengan memahami aspek medikolegal dan tata laksana PTK maka diharapkan akan meminimalisir dan menghindari tuntutan hukum dari pasien.
\end{abstract}

Kata kunci: aspek medikolegal, persetujuan tindakan kedokteran, tata cara

\begin{abstract}
Informed consent is mandatory for the physician before taking medical treatment. Lack of informed consent may elicit complaints and or claims from both the patient and the family and may cause legal problems for the physician. This literature review aims to discuss medicolegal aspect and procedures in the process of obtaining of informed consent for doctors in hospitals and in other health care facilities. The history, philosophy, definitions, legal basis, objectives, medicolegal aspects and the procedure of informed consent are discussed to improve understanding of the informed consent process. By improving the understanding medicolegal aspect and procedure of informed consent is expected to minimize and avoid the lawsuit from patients.
\end{abstract}

Keywords: informed consent, medicolegal aspect, procedure

*Korespondensi: Dedi Afandi, email: dediafandi4n6@gmail.com

Artikel info: Online published first 25 April 2018; Received 4 Maret 2018; Accepted 5 Maret 2018.

DOI: https://doi.org/10.26891/jkm.v1i2.2018.99-105

Copyright @ 2018 Dedi Afandi. This is an open access article distributed under the terms of the Creative Commons Attribution-NonCommercial 4.0 International License (http://creativecommons.org/licenses/by-nc/4.0/), which permits unrestricted non-commercial use, distribution, and reproduction in any medium, provided the original author and source are properly cited. 
Persetujuan Tindakan Kedokteran (PTK) atau yang lebih dikenal dengan informed consent merupakan salah satu kewajiban yang harus dilakukan oleh dokter sebelum melakukan tindakan medis. Persetujuan atau penolakan terhadap suatu tindakan medis yang akan dilakukan oleh dokter harus didapatkan dari pasien. ${ }^{1}$ Pelaksanaan PTK yang kurang adekuat atau tidak sesuai dengan prosedur dapat menimbulkan komplain dan atau klaim baik dari pasien maupun keluarga serta dapat menimbulkan masalah hukum bagi dokter. Hasil penelitian menunjukkan bahwa PTK yang kurang adekuat merupakan salah satu hal yang paling sering dilaporkan oleh pasien pada kasus malpraktik medis. Penelitian di Australia melaporkan sebanyak 3,4\% dari 7846 kasus malpraktik dan $11.5 \%$ dari 1898 komplain pasien berhubungan dengan PTK dari seluruh dokter spesialis dan dokter umum. ${ }^{2}$ Persetujuan tindakan kedokteran inadekuat dilaporkan lebih tinggi di Amerika Serikat pada kasus malpraktik medis tindakan operasi kosmetik payudara yaitu $43,8 \%{ }^{3}$

Sementara itu pasien juga mengeluhkan PTK yang dilakukan oleh dokter, penelitian di sebuah rumah sakit di Jakarta melaporkan bahwa sebanyak 66,3\% kualitas informasi yang diberikan dokter masih kurang, ${ }^{4}$ hasil ini kurang lebih sama dengan penelitian di Arab Saudi ${ }^{5}$ yang melaporkan bahwa pada umumnya PTK berkualitas kurang baik, dilaksanakan sebatas rutinitas dan hampir setengah dari pasien takut untuk mengungkapkan penolakan terhadap tindakan medis yang akan dilakukan. Demikian juga dengan pengalaman penulis dalam mendampingi kasus sengketa medis, masih sering ditemukan tata cara serta format PTK yang belum sesuai dengan standar pada beberapa rumah sakit, sehingga akan melemahkan posisi dokter di mata hukum.

Berdasarkan uraian di atas penting bagi dokter untuk memahami aspek medikolegal dan melaksanakan PTK sesuai dengan peraturan yang berlaku agar dapat meminimalisir dan menghindari tuntutan dari pasien. Tinjauan pustaka ini bertujuan untuk membahas aspek medikolegal dan tata laksana dalam proses melakukan PTK bagi dokter baik di rumah sakit maupun di fasilitas pelayanan kesehatan lainnya.

\section{METODE}

Penulisan artikel ini berdasarkan studi kepustakaan, dan peraturan perundang-undangan yang berlaku di Indonesia yang berhubungan dengan persetujuan tindakan kedokteran (PTK) terutama tentang aspek medikolegal dan tata laksana.

\section{HASIL DAN PEMBAHASAN}

\section{Sejarah dan Filosofi}

Sebelum tahun 1950-an hubungan dokter-pasien adalah hubungan yang bersifat paternalistik, dengan prinsip utama adalah beneficence. Sifat hubungan paternalistik ini kemudian dinilai telah mengabaikan hak pasien untuk turut menentukan keputusan. Sehingga mulai tahun 1970-an dikembangkan hubungan kontraktual. Konsep ini muncul berkaitan dengan hak menentukan nasib sendiri (the right to self-determination) sebagai dasar hak asasi manusia dan hak atas informasi yang dimiliki pasien tentang penyakitnya sebagai mana yang tertuang dalam Declaration of Lisbon (1981) dan Patients' Bill of Right (American Hospital Association,1972) pada intinya menyatakan "pasien mempunyai hak menerima dan menolak pengobatan, dan hak untuk menerima informasi dari dokternya sebelum memberikan persetujuan atas tindakan medis".6,9-11

Prinsip autonomi pasien ini dianggap sebagai dasar dari doktrin informed consent. Tindakan medis terhadap pasien harus mendapat persetujuan (autorisasi) dari pasien tersebut, setelah ia menerima dan memahami informasi yang diperlukan. secara moral maupun hukum, tidak ada seorang pun, baik dokter maupun pasien, dapat berbuat sesuatu terhadap tubuh seseorang tanpa persetujuan dari yang memiliki tubuh tersebut, karena hal itu merupakan tindakan melanggar etika, hukum perdata maupun hukum pidana. Oleh sebab itu hanya pasien sendiri yang berhak untuk menentukan apa yang terbaik terhadap dirinya sendiri. ${ }^{6-8,10-12}$

\section{Definisi, Dasar Hukum, dan Tujuan}

Persetujuan tindakan kedokteran (PTK) adalah merupakan terjemahan yang dipakai untuk istilah informed consent. Konsep tentang informed consent mempunyai dua unsur : (1) informed atau informasi yang harus diberikan oleh dokter dan (2) consent atau persetujuan yang diberikan pasien, dalam arti pasien harus mengerti untuk apa persetujuan itu diberikan. Jadi informed consent adalah persetujuan yang diberikan pasien kepada dokter setelah diberi penjelasan. ${ }^{7,8,12}$

Istilah Persetujuan Tindakan Kedokteran (PTK) resmi dipakai setelah diterbitkannya Peraturan Menteri Kesehatan Republik Indonesia Nomor 290/MENKES/PER/III/2008 tentang Persetujuan Tindakan Kedokteran, yang mendefinisikan bahwa "Persetujuan tindakan kedokteran adalah persetujuan yang diberikan pasien atau keluarga terdekat setelah mendapat penjelasan lengkap 
mengenai tindakan kedokteran atau kedokteran gigi yang akan dilakukan terhadap pasien". ${ }^{13}$ Pengertian PTK di sini bukanlah semata-mata mendapatkan persetujuan atau izin tertulis dari pasien pada tindakan operatif atau tindakan invasif lainnya yang berisiko tinggi namun lebih jauh ditekankan bahwa adanya kesepakatan yang dicapai setelah dokter dan pasien berdialog. Jadi PTK merupakan suatu proses yang menunjukkan komunikasi yang efektif antara dokter dengan pasien, dan bertemunya pemikiran tentang apa yang akan dan apa yang tidak akan dilakukan terhadap pasien. $16,7,12,14 \quad$ Babar $^{15}$ menyatakan bahwa: "Informed consent is a process to some extend but lays essential emphasis on what the patient would want to know, including about adverse effects, risk of failure, alternative choices and how that individual patients could be affected by the treatment of if its lack. Here, the patient decides on what he wants to know". Jadi dalam pelaksanaannya PTK minimal harus membuat pasien mengerti (informed) dalam kontek pemberian informasi sebelum pasien memberikan persetujuan (consent). Idealnya ini baru bisa terlaksana apabila terdapat komunikasi yang efektif dan bertemunya pemikiran yang sepakat sebelum mencapai persetujuan.

Dasar hukum persetujuan tindakan kedokteran adalah Pasal 45 Undang-Undang Nomor 29 Tahun 2004 tentang Praktik Kedokteran, dan Pasal 37 Undang-Undang Nomor 44 Tahun 2009 tentang Rumah Sakit. Peraturan pelaksananya adalah Peraturan Menteri Kesehatan Republik Indonesia Nomor 290/MENKES/PER/III/2008 tentang Persetujuan Tindakan Kedokteran. Sumber bacaan lain yang terkait dengan PTK adalah buku yang dikeluarkan oleh Konsil Kedokteran Indonesia: Penyelenggaraan Kedokteraan yang Baik di Indonesia, dan Manual Persetujuan Tindakan Kedokteran. Dari sisi etik, PTK wajib dilaksanakan oleh dokter sesuai dengan Pasal 10 Kode Etik Kedokteran Indonesia, yaitu:" Seorang dokter wajib senantiasa menghormati hak-hak- pasien, teman sejawatnya, dan tenaga kesehatan lainnya, serta wajib menjaga kepercayaan pasien". 1,13,16,17

Ada 2 tujuan utama dari persetujuan tindakan kedokteran yaitu: (1). Melindungi pasien terhadap segala tindakan medik yang dilakukan tanpa sepengetahuan pasien, misalnya hendak dilakukan prosedur medik yang sebenarnya tidak perlu dan tanpa ada dasar mediknya, (2). Memberikan perlindungan hukum kepada dokter terhadap akibat yang tak terduga dan bersifat negatif. Perlindungan hukum yang dimaksud di sini adalah perlindungan yang terbatas pada keadaan "risk of treatment" yang tak mungkin dihindarkan, walaupun sang dokter sudah berusaha sedapat mungkin dan bertindak dengan sangat hati-hati dan teliti. Karena setiap tindakan medis yang dilakukan oleh dokter, terkadang hasilnya bersifat ketidakpastian (uncertainty) dan tidak dapat diperhitungkan secara matematik karena dipengaruhi oleh faktor-faktor lain yang berada di luar kekuasaan dan kontrol dokter, misalnya virulensi penyakit, kepatuhan pasien, kualitas obat dan sebagainya. ${ }^{7,9,12,18}$

Persetujuan tindakan kedokteran sesungguhnya merupakan kunci keberhasilan dalam hubungan dokter-pasien, karena: a). melindungi otonomi pasien, di mana dengan memberikan persetujuan atau tidak, ia menentukan hidupnya sendiri; b). melindungi martabat manusia, di mana pasien diakui sebagai pusat nilai yang tidak boleh digunakan sebagai sarana belaka untuk tujuan lain di luar dirinya; c). berfungsi untuk memperlihatkan bahwa pasien tidak dimanipulasi; d). menciptakan suasana saling percaya antara dokter-pasien: dan e). membantu kelancaran jalannya pemeriksaanpengobatan, di mana dengan mengetahui lebih banyak tentang tindakan yang akan dilakukan, umumnya pasien dapat memberi informasi lebih baik, dapat bekerja sama lebih intensif, dan lebih taat memenuhi persyaratan-persyaratan yang diminta berkaitan dengan proses penyembuhan. 7,8,12,14

\section{Aspek Medikolegal Persetujuan Tindakan Kedokteran}

Elemen persetujuan tindakan kedokteran

Menurut Beuchamp dan Childress, ${ }^{12}$ persetujuan tindakan kedokteran (baca: Informed consents) memiliki 3 elemen, yaitu:

(A) Threshold elements (precondition)

1. Competence (to understand \& decide)

2. Voluntariness (in deciding)

(B) Information elements

1. Disclosure (of material information)

2. Recommendation (of a plan)

3. Understanding (of 3 \& 4)

(C) Consent elements

4. Decision (in favor of a plan)

5. Authorization (of the chosen plan)

Urutan elemen di atas merupakan suatu hierarkisitas, dengan kata lain harus dipenuhi berdasarkan urutan yang telah ditentukan.

Pasien yang kompeten menurut Permenkes adalah pasien dewasa atau bukan anak menurut peraturan 
perundang-undangan atau telah/pernah menikah, tidak terganggu kesadaran fisiknya, mampu berkomunikasi secara wajar, tidak mengalami kemunduran perkembangan (retardasi) mental dan tidak mengalami penyakit mental sehingga mampu membuat keputusan secara bebas. ${ }^{13}$ Batas umur pasien dikategorikan kompeten menurut peraturan perundang-undangan yang berlaku di Indonesia adalah berusia 18 tahun atau lebih. Tiga kata kunci untuk kriteria pasien kompeten yaitu: dewasa, sadar, dan sehat secara mental. Ketiga hal ini harus terpenuhi, apabila salah satu tidak terpenuhi maka informasi dan persetujuan, diberikan dan dimintakan kepada keluarga terdekat. Selain syarat kompeten, maka sebelum diberikan informasi, pasien juga harus berada dalam keadaan bebas atau sukarela untuk menerima informasi dan memberi persetujuan. $7,10,12,18,19$

Informasi yang diberikan harus dapat membuat pasien memahami akan situasi dan kondisi penyakitnya, memahami risiko atas keputusan yang akan dibuatnya dan berkomunikasi dengan dokter perihal keadaannya dengan dasar pemahaman. Telah ditegaskan bahwa informasi ini harus diberikan baik diminta atau tidak diminta oleh pasien atau keluarga. Informasi ini harus diberikan sedemikian rupa sehingga dapat dijadikan acuan bagi pasien atau keluarganya untuk mengambil keputusan, yaitu menerima atau menolak tindakan medis..$^{7-9,12,18,20,21}$ Dalam pasal 45 ayat 3 UU No. 29/2004 penjelasan atau pemberian informasi kepada pasien sekurangkurangnya mencakup: ${ }^{17}$

a. Diagnosis dan tata cara tindakan medis;

b. Tujuan tindakan medis yang dilakukan;

c. Alternatif tindakan lain dan risikonya;

d. Risiko dan komplikasi yang mungkin terjadi; dan

e. Prognosis terhadap tindakan yang dilakukan. Informasi yang diberikan haruslah informasi yang adekuat, dalam hal ini seberapa baik informasi yang harus diberikan kepada pasien, dapat dilihat dari 3 standar, yaitu: $:^{7,12,14,18,20}$

a. Reasonable physician standard, bahwa kewajiban memberikan informasi dan criteria ke-adekuat-an informasi ditentukan bagaimana biasanya dilakukan dalam komunitas tenaga medis. Standar ini terlalu mengacu kepada nilai-nilai yang ada dalam komunitas kedokteran, tanpa memperhatikan keingintahuan dan kemampuan pemahaman individu yang diharapkan menerima informasi tersebut. b. Subjective standard, bahwa keputusan harus didasarkan atas nilai-nilai yang dianut oleh pasien secara pribadi, sehingga informasi yang diberikan harus memadai untuk pasien tersebut dalam membuat keputusan. Standar ini sangat sulit dilaksanakan atau hampir mustahil. Adalah mustahil bagi tenaga medis untuk memahami nilai-nilai yang secara individual dianut oleh pasien.

c. Reasonable patient standard, standar ini merupakan hasil kompromi dari kedua standar sebelumnya, yaitu dianggap cukup apabila informasi yang diberikan telah memenuhi kebutuhan pada umumnya orang awam.

Informasi harus diberikan dengan itikad baik, secara jujur dan tidak bersifat menakut-nakuti atau memaksa. Informasi juga harus diberikan dalam Bahasa yang mudah untuk dimengerti atau cara lain yang bertujuan untuk memudahkan pemahaman (seperti video, media cetak). Penjelasan informasi diberikan oleh dokter atau dokter gigi yang merawat pasien, dan apabila berhalangan hanya boleh didelegasikan pada dokter atau dokter gigi lain yang kompeten. ${ }^{13}$

Persetujuan memiliki lingkup terbatas pada hal-hal yang telah dinyatakan sebelumnya, tidak dapat dianggap sebagai persetujuan atas semua tindakan yang akan dilakukan, serta penting diperhatikan disini adalah siapa yang berhak memberikan persetujuan. Apabila pasien tidak diberikan informasi sebelumnya, maka PTK yang walaupun sudah ditandatangani tidak merupakan bukti kuat bagi dokter, karena pasien dianggap belum informed sehingga belum terdapat persetujuan dalam arti yang sebenarnya. Seperti halnya pemberian informasi atau penjelasan, maka untuk persetujuan juga harus dilakukan atau diberikan oleh pasien yang kompeten. Apabila pasien tidak kompeten maka persetujuan dapat dilakukan atau diberikan oleh keluarga terdekat (next of kin). ${ }^{6}$ $8,12,13,19$

\section{Bentuk persetujuan tindakan kedokteran}

Terdapat 2 bentuk persetujuan tindakan kedokteran yaitu:

1. Tersirat atau dianggap telah diberikan (implied consent)

Pasien tidak menyatakannya, baik secara lisan maupun tertulis, namun melakukan tingkah laku (gerakan) yang menunjukkan jawabannya. Meskipun persetujuan jenis ini tidak memiliki bukti, namun jenis inilah yang paling banyak dilakukan dalam praktek sehari-hari. Misalnya seseorang yang menggulung 
baju dan mengulurkan lengannya untuk diambil darahnya.

2. Dinyatakan (expressed consent): lisan atau tulisan Pernyataan tertulis diperlukan apabila dibutuhkan bukti di kemudian hari, umumnya pada tindakan invasif atau yang berisiko tinggi mempengaruhi kesehatan pasien secara bermakna. Dalam Permenkes menyatakan bahwa setiap tindakan bedah (operasi) dan tindakan beresiko tinggi lainnya harus dengan persetujuan tertulis yang ditandatangani oleh yang hendak memberikan persetujuan. Selain keadaan di atas persetujuan tindakan medik dapat diberikan secara lisan atau tersirat. ${ }^{7,12,13}$

Persetujuan tindakan kedokteran pada keadaan emergensi dan khusus

Dalam keadaan gawat darurat, untuk menyelamatkan jiwa pasien dan atau mencegah kecacatan tidak diperlukan PTK. Pada keadaan emergensi dimana didampingi oleh keluarga terdekat, maka persetujuan dapat dimintakan kepada keluarga terdekat (next of kin) dengan urutan sebagai berikut : suami/isteri yang sah, anak kandung, ayah atau ibu kandung, saudara kandung atau pengampunya. $1,7,8,12,13,15$

Demikian juga hal nya dalam hal tindakan kedokteran harus dilaksanakan sesuai dengan program pemerintah dimana tindakan medik itu untuk kepentingan masyarakat banyak, maka PTK tidak diperlukan. ${ }^{13}$

\section{Sanksi-sanksi}

Apabila tindakan medik dilakukan tanpa persetujuan pasien maka dapat dikenakan sanksi-sanksi sebagai berikut: ${ }^{1,7,8,13,16,17}$

1. Sanksi etik, mulai dari teguran lisan sampai dengan rekomendasi pencabutan surat ijin praktik.

2. Sanksi administratif, dapat berupa teguran lisan, teguran tertulis sampai dengan pencabutan surat ijin praktik.

3. Sanksi disiplin, dapat berupa tegulisan lisan, tertulis, rekomendasi pencabutan surat ijin praktik dan atau kewajiban mengikuti Pendidikan atau pelatihan di institusi Pendidikan kedokteran.

4. Sanksi Perdata

Suatu tindakan medik terhadap seorang pasien tanpa memperoleh persetujuan dahulu dari pasien tersebut dapat dianggap sebagai penyerangan atas hak orang lain atau perbuatan melanggar hukum (tort). Dalam hal ini dokter dapat menerima sanksi sebagaimana diungkapkan dalam ketentuan pasal 1365 Kitab Undang-Undang Hukum Perdata : “Tiap perbuatan melanggar hukum, yang membawa kerugian kepada orang lain, mewajibkan orang yang karena salahnya menerbitkan kesalahan itu, mengganti kerugian tersebut".

5. Sanksi Pidana

Suatu tindakan medik yang dilakukan oleh dokter tanpa persetujuan pasien dapat dianggap melanggar peraturan Kitab Undang-Undang Hukum Pidana pasal 351 mengenai penganiayaan. Menyentuh atau melakukan tindakan terhadap pasien tanpa persetujuan dapat dikategorikan sebagai "penyerangan" (assault).

\section{Tata Cara Persetujuan Tindakan Kedokteran}

Hal pertama yang harus dilakukan untuk mempermudah dan menghindari kealfaan dalam melaksanakan PTK adalah mencari format yang tepat, benar, dan sesuai dengan peraturan perundangundangan yang berlaku di Indonesia. Sepanjang pengetahuan penulis, format yang memenuhi kriteria tersebut adalah contoh format PTK yang dikeluarkan oleh Konsil Kedokteran Indonesia yang dimuat dalam buku Manual Persetujuan Tindakan Kedokteran.(1) (Gambar 1)

Langkah-langkah yang dilakukan untuk mendapatkan PTK yang baik adalah:1,7-9,13,14,18-21

1. Evaluasi kompetensi pasien apakah pasien kompeten untuk dapat menerima informasi dan memberi persetujuan. Bila tidak kompeten maka proses PTK dilakukan pada keluarga terdekat atau wali nya.

2. Lakukan penilaian keadaan apakah informasi akan memperburuk kondisi pasien.

3. Lakukan pada tempat dan situasi yang membuat pasien nyaman untuk menerima informasi.

4. Tanyakan kepada pasien apakah membutuhkan pendampingan dari keluarga terdekat.

5. Dalam melakukan proses PTK sebaiknya dokter didampingi oleh tenaga kesehatan lain.

6. Berikan informasi secara jelas, adekuat, serta menggunakan bahasa yang dapat dipahami oleh pasien, bila diperlukan dapat digunakan alat bantu untuk menjelaskan.

7. Tanyakan kembali pemahaman pasien atas informasi yang telah diberikan.

8. Beri kesempatan kepada pasien untuk bertanya dan berdiskusi. 


\begin{tabular}{|c|c|c|c|}
\hline \multicolumn{4}{|c|}{ PEMBERIAN INFORMASI } \\
\hline \multicolumn{4}{|c|}{ Dokter Pelaksana Tindakan } \\
\hline \multicolumn{4}{|c|}{ Pemberi informasi } \\
\hline \multicolumn{4}{|c|}{$\begin{array}{l}\text { Penerima Informasi / pemberi } \\
\text { persetujuan * }\end{array}$} \\
\hline & JENIS INFORMASI & ISI INFORMASI & TANDA (v) \\
\hline 1 & Diagnosis (WD \& DD) & & \\
\hline 2 & Dasar Diagnosis & & \\
\hline 3 & Tindakan Kedokteran & & \\
\hline 4 & Indikasi Tindakan & & \\
\hline 5 & Tata Cara & & \\
\hline 6 & Tujuan & & \\
\hline 7 & Risiko & & \\
\hline 8 & Komplikasi & & \\
\hline 9 & Prognosis & & \\
\hline \multirow[t]{2}{*}{10} & Alternatif \& Risiko & & \\
\hline & Lain-lain & & \\
\hline \multicolumn{3}{|c|}{$\begin{array}{l}\text { Dengan ini menyatakan bahwa saya telah menerangkan hal-hal di atas } \\
\text { secara benar dan jelas dan memberikan kesempatan untuk bertanya dan/atau } \\
\text { berdiskusi }\end{array}$} & tandatangan \\
\hline \multicolumn{3}{|c|}{$\begin{array}{l}\text { Dengan ini menyatakan bahwa saya telah menerima informasi sebagaimana } \\
\text { di atas yang saya beri tanda/paraf di kolom kanannya, dan telah } \\
\text { memahaminya }\end{array}$} & tandatangan \\
\hline \multicolumn{4}{|c|}{$\begin{array}{l}\text { * Bila pasien tidak kompeten atau tidak mau menerima informasi, maka penerima informasi adalah } \\
\text { wali atau keluarga terdekat }\end{array}$} \\
\hline \multicolumn{4}{|c|}{ PERSETUJUAN TINDAKAN KEDOKTERAN } \\
\hline \multicolumn{4}{|c|}{$\begin{array}{l}\text { Yang bertandatangan di bawah ini, saya, nama ___ umur } \\
\text { tahun, laki-laki/ perempuan*, alamat }\end{array}$} \\
\hline \multicolumn{4}{|c|}{ 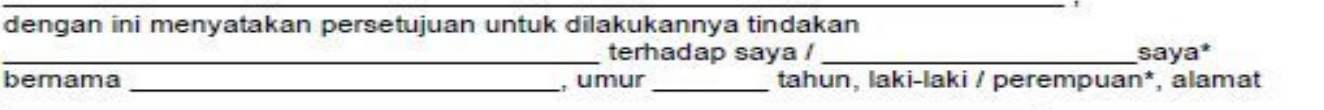 } \\
\hline \multicolumn{4}{|c|}{$\begin{array}{l}\text { Saya memahami perlunya dan manfaat tindakan tersebut sebagaimana telah dijelaskan seperti di } \\
\text { atas kepada saya, termasuk risiko dan komplikasi yang mungkin timbul. } \\
\text { Saya juga menyadari bahwa oleh karena ilmu kedokteran bukanlah ilmu pasti, maka keberhasilan } \\
\text { tindakan kedokteran bukanlah keniscayaan, melainkan sangat bergantung kepada izin Tuhan Yang } \\
\text { Maha Esa. }\end{array}$} \\
\hline \multicolumn{4}{|c|}{ 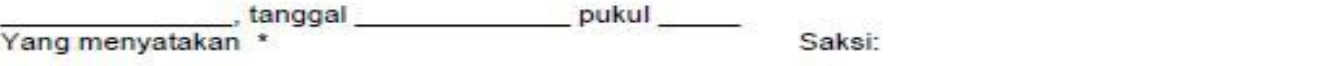 } \\
\hline 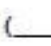 & $(-$ & ( & ) \\
\hline
\end{tabular}

Gambar 1. Contoh format persetujuan tindakan kedokteran ${ }^{1}$

9. Beri kesempatan kepada pasien, apabila mereka membutuhkan waktu untuk mendiskusikan informasi tersebut dengan keluarga, akan tetapi berikan juga batas waktu kapan keputusan akan didapatkan.

10. Bila pasien menyatakan persetujuan atau penolakan maka mintalah tanda tangan pasien dan 1 orang saksi dari keluarga pasien pada tempat yang telah disediakan.

11. Dokumentasikan dengan baik proses PTK tersebut sesuai format yang digunakan, serta catatlah waktu kapan tahapan proses pemberian informasi diberikan dan kapan persetujuan atau penolakan dari pasien diputuskan.
Beberapa hal yang harus diperhatikan adalah: 1). Sedapat mungkin informasi dijelaskan oleh dokter yang akan melakukan tindakan kedokteran, 2). Bila dokter berhalangan maka pemberi informasi dapat didelegasikan pada dokter lain yang kompeten, 3) Di akhir proses pemberian informasi, dokter dan pasien membubuhkan tanda tangan pada kolom yang disediakan, 4). Persetujuan sebaiknya diberikan langsung oleh pasien, namun bila tidak memungkinkan dapat diwakili oleh keluarga, dan 5). Dokter tidak perlu membubuhkan tanda tangan pada bagian persetujuan. ${ }^{1,7,8,13}$

Format yang dibuat oleh Konsil Kedokteran Indonesia, secara garis besar membagi dokumen PTK ke dalam 2 bagian, yaitu bagian pemberian informasi 
dan baian persetujuan. Hal ini sesuai 3 elemen dari PTK. Kesalahan yang sering terjadi adalah pada bagian persetujuan, dokter ikut menandatangani. Harus dipahami bahwa PTK adalah persetujuan sepihak dari pasien atas tindakan kedokteran yang akan dilakukan, jadi bukanlah merupakan suatu perjanjian atau kontrak. ${ }^{1,12}$

\section{SIMPULAN}

Persetujuan tindakan kedokteran (PTK) bersifat mandatory yang harus dilaksanakan oleh dokter sebelum tindakan kedokteran dilakukan. Proses PTK merupakan proses sekaligus hasil komunikasi efektif

\section{DAFTAR PUSTAKA}

1. Konsil Kedokteran Indonesia. Manual persetujuan tindakan kedokteran. Jakarta: Konsil Kedokteran Indonesia; 2006. 36 p.

2. Bismark MM, Gogos AJ, Clark RB, Gruen RL, Gawande AA, Studdert DM. Legal disputes over duties to disclose treatment risks to patients: A review of negligence claims and complaints in Australia. PLoS Med. 2012:9(8); e1001283. doi: 10.1371/journal.pmed.1001283

3. Paik AM, Mady LJ, Sood A, Eloy JA, Lee ES. A look inside the courtroom: an analysis of 292 cosmetic breast surgery medical malpractice cases. Aesthetic Surg J. 2014;34(1):79-86.

4. Afandi D, Sampurna B, Siswadja TD, Widjaja IR. Association between consultation frequency and satisfaction and information quality of informed consent for preoperative elective surgery patients. J Indones Med Assoc. 2011;58(5):153-7.

5. Abolfotouh MA, Adlan AA. Quality of informed consent for invasive procedures in central Saudi Arabia. Int J Gen Med. 2012; 5:269-75.

6. Beauchamp TL. Informed consent: Its history, meaning, and present challenges. Cambridge Q Healthc Ethics. 2011;20(4):515-23.

7. Sampurna B, Siswaja TD SZ. Bioetik dan hukum kedokteran. Jakarta: Pustaka Dwipar; 2005. p 75- 84.

8. Guwandi J. Informed consent. Jakarta: Balai Penerbit Fakultas Kedokteran Universitas Indonesia; 2004. 50 p.

9. Jones JW, McCullough LB. How informed need be informed consent? J Vasc Surg. 2011;54(6):1830-1.

10. Rathor MY, Rani MFA, Shah AM, Akter SF. Informed consent: A Socio-legal study. Med J Malaysia. 2011;66(5):423-8.

11. Sivalingam N. Medical paternalism and patient autonomy; The dualism doctors contend with. Med J Malaysia. 2011;66(5):421-2.

12. Beauchamp TL, Childress JF. Principles of Biomedical Ethics. 7 Ed. New York: Oxford University Press;2013. p. 120-5.

13. Peraturan Menteri Kesehatan Republik Indonesia Nomor 290/MENKES/PER/III/2008 tentang Persetujuan Tindakan Kedokteran.

14. White MK, Keller V, Horrigan LA. Beyond informed consent: The shared decision-making process. JCOM. 2003;10(6):323-8. antara pasien dan dokter, serta bukan sekedar penandtanganan formulir PTK belaka. Persetujuan tindakan kedokteran adalah pernyataan sepihak dari pasien dan bukan perjanjian antara pasien dengan dokter, sehingga dapat ditarik kembali setiap saat. Dengan memahami aspek medikolegal dan tata laksana PTK maka diharapkan akan meminimalisir dan menghindari tuntutan dari pasien.

\section{KONFLIK KEPENTINGAN}

DA merupakan editor, akan tetapi tidak terlibat dalam proses review artikel ini.

15. Babar SMA. True consent, informed consent and the english law. Anil Aggrawal's Internet Journal of Forensic Medicine and Toxicology. 2004:5(2). [cited 2017 Nov 25] available from: http://anilaggrawal.com/ij/vol_005_no_002/papers/ paper002.html

16. Ikatan Dokter Indonesia. Kode Etik Kedokteran Indonesia. Jakarta: IDI; 2004. p. 34-7

17. Undang-Undang Republik Indonesia Nomor 29 Tahun 2004 tentang Praktik Kedokteran.

18. Raab EL. The parameters of informed consent. Trans Am Ophthalmol Soc. 2004; 102:225-32.

19. Kluge EHW. Incompetent patients, substitute decision making, and quality of life: some ethical considerations. Medscape J Med. 2008;10(10):237. PMC2605131.

20. Murray B. Informed Consent: What Must a Physician Disclose to a Patient? Virtual Mentor. 2012;14(7):563-6.

21. Nair K, Dolovich L, Cassels A, McCormack J, Levine M, Gray J, et al. What patients want to know about their medications. Focus group study of patient and clinician perspectives. Can Fam Physician. 2002;48:104-10 